\title{
Article \\ Will Islamic Water Management Principles Be Included If the Helmand River Treaty Is Revisited?
}

\author{
Najibullah Loodin ${ }^{1, *(D)}$ and Aaron T. Wolf ${ }^{2}$ (D) \\ 1 Research Center, Ghalib University, Herat 3001, Afghanistan \\ 2 Professor of Geography, College of Earth, Ocean and Atmospheric Sciences, 104 CEOAS Administration \\ Building, Oregon State University, Corvallis, OR 97331, USA; Aaron.Wolf@oregonstate.edu \\ * Correspondence: loodin2234@gmail.com; Tel.: +93-798-697-629
}

Citation: Loodin, N.; Wolf, A.T. Will Islamic Water Management Principles Be Included If the Helmand River Treaty Is

Revisited? Water 2022, 14, 67. https://doi.org/10.3390/ w14010067

Academic Editor: Athanasios Loukas

Received: 3 October 2021

Accepted: 17 December 2021

Published: 31 December 2021

Publisher's Note: MDPI stays neutral with regard to jurisdictional claims in published maps and institutional affiliations.

Copyright: (C) 2021 by the authors. Licensee MDPI, Basel, Switzerland. This article is an open access article distributed under the terms and conditions of the Creative Commons Attribution (CC BY) license (https:// creativecommons.org/licenses/by/ $4.0 /)$.

\begin{abstract}
Despite the importance of water management in Islamic culture, the role of religion has been underemphasized by scholars. Using the three criteria of equity, responsibility and sustainability, this study aims to assess whether Islamic water management principles are incorporated into the revision of the transboundary Helmand River Basin under the administration of the Taliban regime. In August 2021, Taliban returned to power in Afghanistan, with a goal of ruling Afghanistan based on Islamic Sharia law, presumably including the management of the transboundary watercourses. One such basin is the Helmand, shared with the downstream Islamic Republic of Iran, with whom Afghanistan will likely revisit the transboundary Helmand River Treaty, possibly based on Islamic water management principles. We examine how principles of Islamic code may influence future negotiations, including the construction of dams on the upper Helmand River Basin initiated under the former administration.
\end{abstract}

Keywords: Islamic water management principles; Taliban; international water law principles; Helmand River Basin; upstream/downstream state

\section{Introduction}

Freshwater is one of the only natural resource on earth that is used for various purposes by different communities. Along its way, the flow of water sometimes separates upstream and downstream users whose values, beliefs, language, race, culture, law and attitudes are different [1]. Historically, communities with a shared watercourse have had conflict over how the water should be divided, managed and utilized. However, the intensity of the conflict is directly associated with the power imbalance and geographic location of the upstream and downstream users [2-4].

Despite the presence of international water law principles, the problems of equity, ownership, allocation and management of water between the riparian states of a shared waterway, including Islamic states, have rarely been addressed in detail [5,6]. Given the rise in water conflict among the upstream and downstream users, some scholars argue that the role of Islam in managing and utilizing natural resources has been underrepresented [5,7,8].

Water plays a vital role in Islamic culture. In fact, Islam has guided its followers to consider equity, justice and sustainability in utilizing natural resources [9]. Some scholars argue that water has been mentioned more than 63 times in the Quran $[10,11]$. The terms nahr (river) and shariba (drinking water) have also been cited 54 and 39 times in the Quran, respectively [10,12]. Similarly, Amery argues that the various forms of precipitation (rainfall, dew and snow) have been cited more than 100 times, including the verse: "And we created from water every living thing" (Quran, 21:30); quoted in [5].

In Islam, water is managed by Islamic Sharia law. In fact, 'Sharia' means "irrigation source" [13-15] or "law of water" [6] (p. 99). There are two basic Sharia concepts that refer to water rights in Islam: "shafa", the right of thirst, which establishes the most 
fundamental right of human beings to quench their thirst and the thirst of their animals; and the "shirb", which is the right to irrigate lands [16]. According to these two basic concepts (shafa and shirb), priorities are given to human and domestic use, and then to animals, agriculture, industrial and recreational activities, respectively [6]. These two basic notions of Sharia (shafa and shirb) are interpreted differently by various Islamic states, given their geographic, social, ethical and cultural differences [5]. Once drinking and domestic use of a community is met, then shirb — the right of irrigation — takes precedence [17]. From an Islamic water management perspective, the upstream users take precedence over the downstream users simply because the flow of the river reaches the upstream users first $[18,19]$. After the settlement of the downstream societies, if new communities are settled upstream, downstream users are first prioritized with water use and then the newly established upstream communities are provided with water use and development [19]. Moreover, hoarding the surplus water is highly prohibited in Islam, even if the needs of the communities are satisfied and met. However, the surplus water is distributed among users according to the mutual agreement or customary laws and regulations in Islamic communities. Despite the differences between the Shiit and Sunni schools of law, the use of shafa and shirb concepts are similar between the Sunni and Shiit schools of law in Islamic nations [1].

Regardless of the differences in implementation of shafa and shirb in Muslim-dominated states, Islam teaches its followers to live in peace and harmony with each other and the ecosystem [20,21]. According to Islamic water management principles, the natural environment belongs to Allah (God), who entrusted it to human beings. Mankind is, thus, responsible for preserving the ecosystem [5].

Using the three criteria, equity, sustainability and responsibility, this study aims to illustrate how Islamic water management principles may be integrated into the revision of the Helmand River Treaty between the Islamic Emirate of Afghanistan and the Islamic Republic of Iran.

\section{Theoretical Framework}

\subsection{Islamic Environmental Theory}

Water resources have been negatively impacted by human-induced climate changes [22]. According to Islamic views, environmental crises occur when humans overuse the Godgiven ecosystem [23]. Perhaps one way to stop the destruction of nature is to redesign environmental policies and regulations according to religious-oriented principles $[6,24]$. Islamic scholars argue that the root of environmental crises is the separation of worldly living and religion $[23,25,26]$.

In the western world, philosophers and environmental ethicists have developed four schools of environmental ethics related to the connection of mankind and nature. These schools are anthropocentrism, biocentrism, liberation/rights theory and eco-centrism [27].

While anthropocentrism or human-centered ethics is the belief that humans alone possess intrinsic values [28], the liberation, or rights, theory asserts that animals also have the same right as mankind [29]. The third school, biocentrism, stresses that every living thing has an intrinsic value regardless of their instrumental value for human beings. The last school of environmental ethics, ecocentrism, emphasizes that natural resources, including non-living resources, have intrinsic value [30].

In contrast, the Islamic view of nature is neither anthropocentric nor ecocentric. It is theocentric (God-centered). According to the theocentric perspective, God (Allah) has created everything in the universe [27,31]. The Quran repeatedly states that nature is created by one (Allah). For instance, "there is no God but He, the Creator of all things" including the nature (Quran, 6:102); quoted in [23]. In fact, the creation of the ecosystem stands as a sign of almighty God [23]. The Quran says, "There are certainly signs in the earth for people with certainty; and in yourselves. Do you not then see?" (Quran, 51:20-21); quoted in [23]. Allah enjoins people to preserve the natural environment [32]. Seyyed Hossain Nasr, an Iranian Islamic scholar, argues that nature is "the theatre wherein are manifested His signs" 
quoted in [32] (p. 15). The relationship between God and nature is the relationship of creator and creature [23]. It is further noted that humans are not the only creatures that need to be protected; so does any living and non-living nature, e.g., forests, lakes and shared watercourses [33]. Allah, for example, says, "There is not an animal (that lives) on Earth. Nor a being that flies on its wings, but (forms a part) of a community like you" (Quran, 6:38); quoted in [33].

Now, we will briefly discuss the three principles of Islamic environmental ethics.

\subsubsection{Principle of Unity (Tawhid)}

According to this principle, God has created the universe including the natural environment. The principle of tawhid shows the interconnectedness of human beings and the ecosystem [34]. The principle of tawhid considers the ecosystem as one of the main creations of Almighty God whose preservation and protection is the duty and responsibility of mankind [5,23].

\subsubsection{Principle of Trusteeship (Khilafah)}

This principle emphasizes the trusteeship of mankind on earth [31]. According to the Islamic perspective, Allah created mankind and appointed him as trustee on earth. Allah, for example, says, "And lo! Your Sustainer said to the angels: Behold, I am about to establish upon earth a Khalifa" (Quran, 2:30); quoted in [23]. The term khalifa (Arabic term for the word trustee), alongside the term fi al-ardh (Arabic word meaning earth) has been cited seven times in the Quran [23]. Each time the term 'Khalifa fi al-ardh' is used, it refers to mankind to whom God entrusted some part of his power on earth. In fact, Allah examines mankind's fairness and justice over things under their stewardship including the natural environment, e.g., rivers, lakes, wetlands, etc. [35].

\subsubsection{Principle of Mizan}

Wickstrom states, "Mizan is the principle that every aspect of creation holds together because there is a balance" [6] (p. 99). It can be inferred that mankind is responsible for the preservation and protection of the ecosystem and nature [6].

If mankind abdicates his/her responsibility, then Allah will punish them. For example, the verse, "mischief has appeared on land and sea because of what the hands of men have done, that Allah may give them a taste of some of their deeds, in order that they may turn back" (Quran, 30:41); quoted in [33], describes the punishment of mankind as the result of ecosystem degradation [36]. Basically, mankind has two responsibilities related to the ecosystem. First, mankind is the preserver and protector of nature. Second, mankind is the user of nature, e.g., using freshwater for irrigation and domestic purposes [12]. Figure 1 illustrates the relationship between Allah, mankind and the ecosystem.

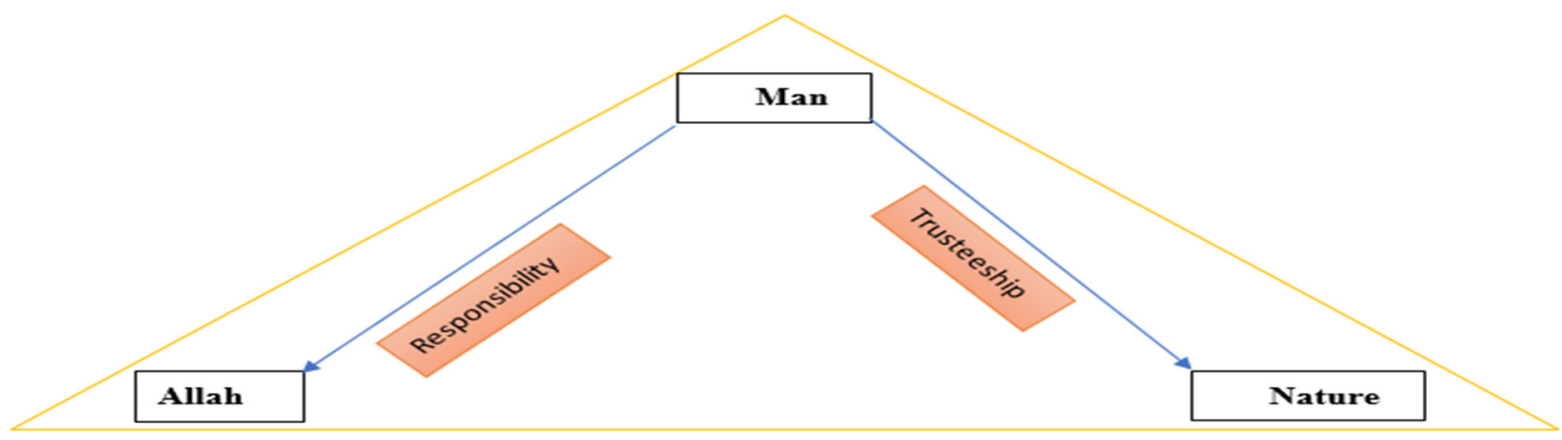

Figure 1. Relationship between Allah, nature and human beings, Source: authors' drawing.

From the responsibility perspective, mankind is the main source of protection for the nature on earth. In fact, mankind is the trustee of Allah who should not pose significant 
harm to nature and the ecosystem $[5,23]$. Nature has been created by Allah so that mankind uses it in a reasonable and sustainable manner [36].

\subsection{Theory of Islamic Water Management}

According to Islamic teachings, water belongs to God who entrusted it to mankind to utilize and transfer it to the next generation without posing significant harm to it [37].

The theory of Islamic water management is based on two important notions: tawhid and fitra. While the notion of tawhid enjoins mankind to utilize natural resources (e.g., water) in a reasonable and sustainable manner, fitra invites people to cooperate with each other at the basin and inter-basin levels [5].

\subsection{International Water Law Principles}

The increase in population, along with reliance on rivers and lakes, led to the emergence of rules and regulations on non-navigational uses of rivers [38]. Various theories and doctrines have emerged stating the practices of riparian states on the use of internationally shared rivers and lakes [39]. We will briefly explain some of these theories.

\subsubsection{Theory of Absolute Territorial Sovereignty}

According to the theory of absolute territorial sovereignty, every nation has the absolute right to utilize the water of an international river flowing in its territory, regardless of its adverse effects on other nations (e.g., the downstream states). The upstream state(s) may control the shared river without considering the hydrological needs of the downstream states [39]. This theory is also called the Harmon Doctrine after the US Attorney General, Mr. Judson Harmon, who declared the absolute right of the US to divert the Rio Grande in 1895. However, this doctrine is no longer used by water experts [38].

\subsubsection{Theory of Absolute Territorial Integrity}

According to this theory, the lower riparian (downstream states) have the right to the full flow of water that crosses the downstream riparian. The theory of absolute territorial integrity is actually the opposite of the theory of absolute territorial sovereignty. In fact, this theory is in favor of the downstream countries of an international watercourse [38]. This theory is no longer used in international watercourse discussion [40].

\subsubsection{Theory of Limited Territorial Sovereignty}

According to this theory, each riparian state has the right to use the shared water resources for free without prejudicing or discriminating the right of any co-riparian state. This theory gives a reciprocal right to each riparian state to utilize natural resources in an equitable manner [38]. The advantage of this theory compared to the other two theories that have just been discussed is that this theory recognizes the right of each upstream and downstream riparian to reasonably and equitably use the shared watercourse. The two principles "equitable and reasonable utilization and obligation not to cause significant harm" are part of this theory [41] (p. 14).

On 21 May 1997, the UN General Assembly adopted the Non-Navigational Uses of International Watercourses, which is also known as the UN Watercourses Convention. This convention codified the principles of international watercourses which were built based on the 1966 Helsinki Rules. As per the request of Turkey, the UN General Assembly called for voting for the adoption of the UN Watercourses Convention. A total of 103 out of 133 countries voted in favor, including Iran; 3 were against and 27 abstained, including Afghanistan [42].

We will briefly discuss the four principles of international water law.

a. Principle of equitable and reasonable utilization.

This principle is a subset of the theory of limited territorial sovereignty. According to this principle, each riparian state has the right to share an international watercourse in a reasonable and equitable manner within its own territory $[39,43]$. This principle is based on 
shared sovereignty. Equality in rights of utilization of a shared river basin does not mean equal share of waters.

\section{b. Principle of Obligation not to cause significant harm.}

This principle is also part of the theory of limited territorial sovereignty [44] (p. 82). This principle stresses that no riparian state in an international basin is allowed to utilize the shared watercourse in its territory in a way that triggers "significant harm" to other basin states or to the environment, including harm to human health or safety and the health of living species in the basin [43]. This principle is widely recognized by international watercourse and environmental law. However, the main question of "significant harm" or how to define harm as 'significant' remains vague and unclear [45].

NOTE: As more than 145 countries share international river basins around the world [46], most international transboundary water agreements do not have the mechanism on public participation [47]. In recent years, the transboundary water agreements have included the public participatory mechanism. For instance, the Environmental Program for the Danube River Basin (1991) included the principle of the broad role of the public in the management and utilization of the transboundary Danube River Basin. Additionally, the wider engagement with different stakeholders, as well as data sharing at the transboundary Nile River Basin, was emphasized in the Nile Basin Initiative [48].

c. Principle of general obligation to cooperate.

It is the responsibility of all the riparian states to cooperate with each other regarding the state of the watercourse and present and future planning use of the shared watercourse [39]. This cooperation will contribute to the sustainable use and protection of the ecosystem $[43,49]$.

d. Principle of Protection and preservation of ecosystems.

The riparian states shall individually and jointly protect and preserve the ecosystems of an international shared basin [39].

Despite being classically and religiously inspired principles, Sharia law is still functional in Muslim states [10]. However, these principles are interpreted differently depending on the doctrines of the particular school of Sharia, and the states where they are applied [1]. When it comes to the issue of water use, governance and management at intra-basin and inter-basin levels, Sharia law differs from western law. First of all, Islamic water law is customary and a morally-inspired principle. Both upstream and downstream riparian states have equal rights, including the rights to water resources [50]. Upstream and downstream users are urged to supply water for those who are in need of water use for their survival or livelihood (e.g., farming and irrigation). If a group or community - whether upstream or downstream state-is not allowed to access water, Allah orders mankind to assist the vulnerable group. Almighty God says, "And why should ye not fight in the cause of God and those who, being weak, are ill-treated (and oppressed)? Men, women and children, whose cry is: 'Our Lord! Rescue us from this town, whose people are oppressors'"' (Quran, 04:75); quoted in [50].

The second difference between international and Islamic-inspired principles is the water right of animals and species. According to these principles, mankind takes precedence in water use over animals. Thirdly, drinking water for both mankind and animals and species is prioritized over agricultural and industrial use [1]. It is worth noting that Sharia is not a national law in the sense that western countries' laws are. In the old age, Islamic Sharia law was applied at the regional and local levels [10]. However, in the modern era, those who adopted have integrated Sharia law into the secular code of law. For instance, Muslim states allow personal issues such as marriage and divorce to be regulated by Sharia law in different ways [51]. Currently both the Islamic Republic of Afghanistan (hereafter, the Islamic Emirate of Afghanistan under the Taliban) and the Islamic Republic of Iran adopt Islamic Sharia law, despite minor differences in Hanafi and Ja'fari's school of law. 
Thus, Sharia law (both Hanafi and Ja'fari) stresses the protection of the under-represented and marginalized communities at the inter-basin level.

\section{Definition of the Three Criteria}

\subsection{Equity}

Equity is the "consideration of fairness, reasonableness, and the policy which is often necessary for the sensible application of the more settled rules of law" [52,53] (p. 26).

In Islam, the main purpose of sending the prophet $(\mathrm{PBUH})$ is to teach justice and equity to the followers [54]. Allah, for example, states, "O you, who have faith, stand firm in equity (qist) as witnesses for Allah, even if it were against yourselves, or your parents, or your relatives. Whether rich or poor, Allah is more worthy of both. Follow not your desires, so that you may be just" (Quran, 4:135); quoted in [55]. In fact, it lays the foundation of justice and equity in Islam [55]. Water users are strongly prohibited from wasting water resources at the inter-basin level [6,55]. There are two basic principles regarding water demand management in the Quran. The first principle is that supplying water is fixed in Islam and the second principle is that water should not be wasted [6]. In line with this argument, the prophet said that 'a man who has access to excessive water and meanwhile refuses allocating water to his brother will be neglected by Allah' (Abu Dawud and authenticated by Al-Albani); quoted in [56]. One can argue that the water rights of the upstream and downstream users in terms of water demand are fixed. Both the upstream and downstream riparian states are responsible for considering equity in a shared watercourse.

\subsection{Responsibility}

In terms of international water law principles, some scholars believe that one of the responsibilities of riparian states is not to pose significant harm to each other and the ecosystem $[7,16,57]$. The over-abstraction of natural resources, which significantly contributed to the degradation of the environment, has raised the question of whether the future generation faces a water crisis or not [58]. In fact, it questions the responsibility of riparian states related to the sustainable utilization of water resources at the inter-basin level.

Responsibility is the most important aspect of Islam. Allah created the world for a purpose and everyone is responsible for his/her doing [59,60]. The verse "When your Lord told the angels, 'I will place a steward on earth', they said, 'Will you put someone there who will corrupt it and shed blood, while we glorify, praise, and sanctify you?' He said, 'I know things you do not know'" (Quran, 2:30); quoted in [61], points to the responsibility of mankind to preserve the ecosystem of the earth [6].

According to this verse, mankind has two responsibilities:

(a) Responsibility to the creator of the universe (Allah);

(b) Responsibility to the creation, e.g., the environment [60].

According to the second responsibility, mankind is responsible for utilizing natural resources in a reasonable manner. This reasonableness should be maintained by both upstream and downstream users of a shared watercourse in Muslim-dominated countries [60], e.g., the Islamic Emirate of Afghanistan and the Islamic Republic of Iran.

\subsection{Sustainability}

Although the term 'sustainability' is widely applied in multidisciplinary studies, its meaning and framework are poorly formulated [62]. The notion of sustainability was first presented by the World Commission on Environment and Development (WCED). Sustainability means to "meet the needs of the present generation without compromising the ability of the future generation to meet their own needs." The term, 'sustainability' is morally and ethically convincing, however, when it comes to planning and decision-making processes (for example, water allocation at the inter-basin level), the term technically fails to offer practical and holistic solutions for sustainable utilization of a shared watercourse 
among riparian states [63]. It is believed that humans and the environment are deeply interconnected from a sustainability point of view; however, no such thing exists as a purely human or purely environmental system [21,62].

Islam, in contrast, stresses that Allah has created natural resources for a purpose [36]. The purpose is to provide livelihood for mankind on earth. It is also believed that the other purpose of creating natural resources is to examine the trusteeship of human beings on earth [36]. As a result of overexploitation of water resources, along with the negative effects of climate change $[25,64]$, the earth is faced with the loss of ecosystems, air pollution, land degradation, river flooding, drought and sea level rise.

In the holy Quran, Almighty Allah has warned mankind of the consequences of overexploitation of water resources. Allah, for example, says, "mischief has appeared on land and sea because of what the hands of men have done, that Allah may give them a taste of some of their deeds, in order that they may turn back" (Quran, 30:41); quoted in [36]. This verse of the Quran sheds light on the negative impacts of over-abstraction of water resources on the livelihood of mankind on earth. The adverse effects of climate change on water resources, e.g., the desiccation of wetlands in Afghanistan and Iran [65,66], alongside the rapid increase in population [6], have affected millions of farmers in the Helmand River Basin [2]. Hence, for a sustainable use of water resources, the upstream and downstream users of a shared watercourse should consider Islamic water law principles [6].

\section{Case Study: The Helmand River Basin}

\subsection{Historical Context}

The Helmand River Basin, which encompasses approximately $45 \%$ of the surface area of Afghanistan, is the largest basin in the country. Approximately $97 \%$ of agricultural lands in the southeastern part of Afghanistan and 80\% of irrigated lands in Sistan-Baluchistan of Iran are irrigated by the Helmand River Basin [67]. The basin is strategically important to both countries.

The prolific lands of the Helmand River Delta surrounded by the deserts of eastern Iran and southwestern Afghanistan have been irrigated for many centuries through the abundance of water of the Helmand River [68]. The use and allocation of water along both sides of the Helmand River Delta has always been very contentious [69]. Since the Afghan-Iranian political border was drawn in 1872, the Helmand River Delta has been recognized as an internationally shared river basin in the region. The Helmand River Basin is an international watercourse that is shared by Afghanistan (81.4\%), Iran (15\%) and Pakistan (3.6\%) [70,71]. As a small portion of the Helmand River is located in Pakistan, scholars do not consider Pakistan as a potential co-riparian in the basin [69].

After the establishment of the Afghan-Iranian political border, conflict over water allocation between Iran and Afghanistan has been on the rise [2,3,71]. It is asserted that both of the neighboring countries made efforts to settle water tension [72,73] through negotiation [68]. The initiation of development in the upstream of the Helmand River Basin (Afghanistan) along with the severe drought in the summer of 1947, however, intensified water conflict among the two riparian states. To settle the water allocation dispute [6,74-79] among the upstream and downstream users of the Helmand River Delta, the US Department of State played the role of a mediator between the two riparian states [68,70,71].

\subsection{Current Context}

There was strong disagreement between the two Islamic states-the Islamic Republic of Iran and the Islamic Emirate of Afghanistan, under Ashraf Ghani's administrationon water allocation of the Helmand Basin [3,66]. Overpopulation [80], drastic climate change $[81,82]$, severe droughts and lack of proper water management mechanism and power imbalance have triggered potential conflict between the upstream and downstream riparian states of the Helmand River Basin [2,69].

According to the 1973 water sharing treaty, Iran's water right is amounted to 22 cubic meters per second, with the option of buying 4 cubic meters per second in normal "water 
years" $[69,83]$. In return, Afghanistan was allowed to use Bandar Abbas port without any restrictions [2,69,84]. Since then, Afghanistan has experienced conflict and civil unrest [85] for almost four decades. Iran, on the other hand, suffered from social unrest in Afghanistan (1990s and 2000s) and entering Afghanistan to divert the water flow of the Helmand River Basin into Iran [84]. As water is now shrinking due to the changing climate, Iran accuses Afghanistan of the desiccation of the wetlands (for more information, see Figure 2).

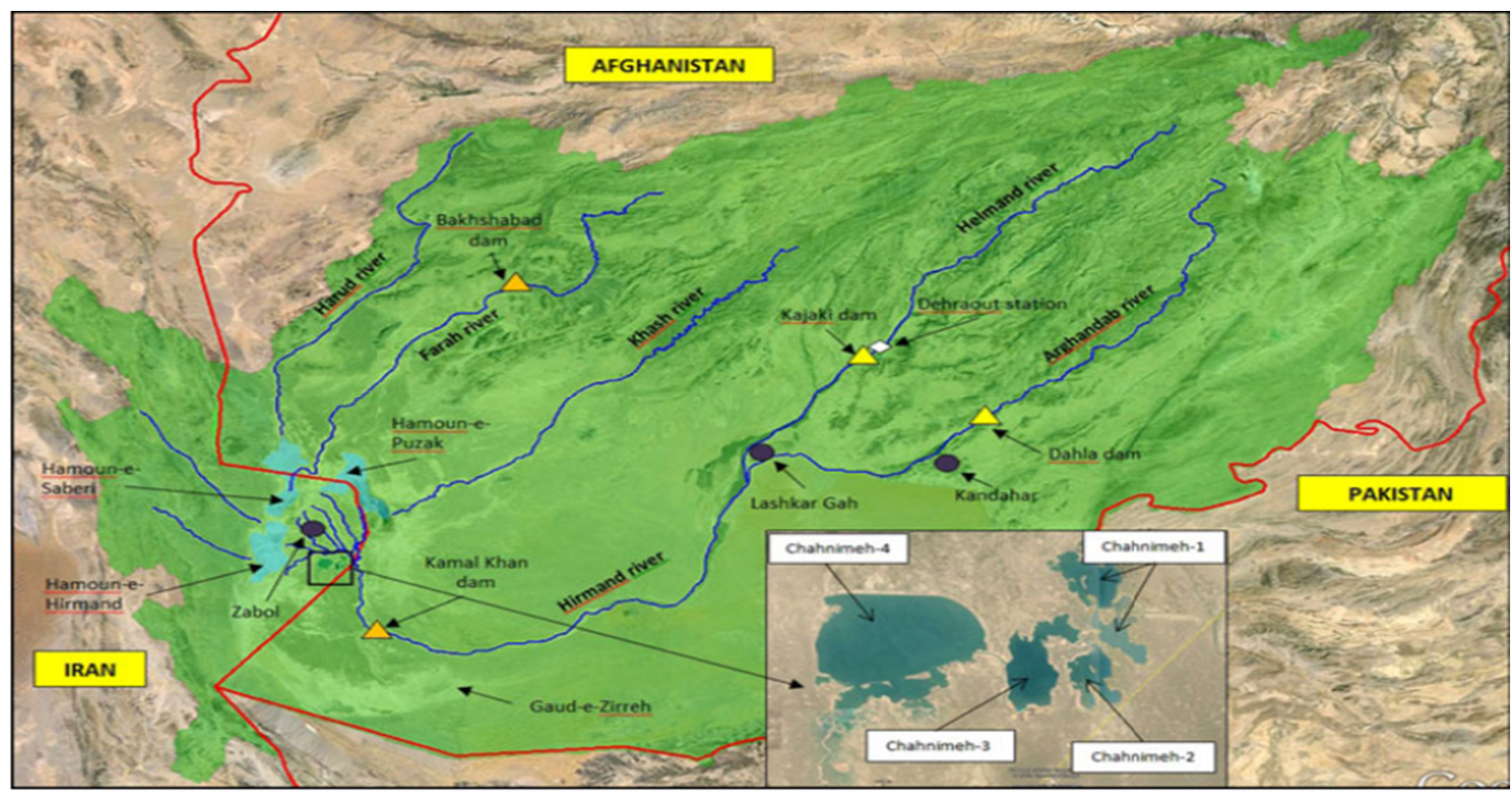

Figure 2. The location of the Hamoun wetlands on both sides of the political border of Iran and Afghanistan [69].

As a late hydraulic mission developer [86], the newly established government of Afghanistan-after the fall of the Taliban regime-had emphasized controlling water within its territory $[65,66,69]$. As a result of the poorly working transboundary water sharing treaty between Iran and Afghanistan [65,83], along with the presence of US-led NATO forces in Afghanistan and drastic climate change [66], the Afghan government has adopted a monolithic resource capturing policy in the upstream Helmand River Basin $[3,65]$. On the other side, using covert and overt tactics, Iran has attempted to disrupt dam construction projects in Afghanistan by equipping anti-government groups, e.g., the Taliban [2,86-90]. The treaty is considered one of the most ineffective water treaties in the region [83,91] because in 1973 the two secular states, Afghanistan and Iran, [91,92] respectively, failed to incorporate culturally based principles such as the inclusion of an Islamic water management approach into the management mechanism of the Helmand River Basin. As a result of the adverse effects of climate change, prolonged droughts, lack of sharing of reliable and accurate hydrological data and lack of cooperation at the transboundary level, the water conflict between the upstream and downstream riparian states has significantly escalated [93-96]. Thus, the main hurdle of the Helmand River Treaty is that it does not address environmental concerns (revitalization of the Hamoun wetlands) and agricultural sustainability [58].

\section{Analysis and Discussion}

\subsection{Equitable and Reasonable Use of Shared Watercourse}

The concept of equity plays an important and central role in utilization, management and protection of shared waterways among co-riparian states [97]. While the principle of equitable and reasonable use of water resources is now being universally understood [97], the concept of equity as a "normative value" entitles each riparian state to use and benefit from the shared waterway. 
While the aim of equitable and reasonable use of a shared watercourse is to allow upstream and downstream users to utilize the shared river basin in an equal manner, McIntyre states, "equality of right does not entitle each State to an equal share in the waters of a shared basin" [97].

Some scholars argue that due to lack of enforcement mechanism, international water law fails to settle water tension among upstream and downstream riparian states [8,98]. In fact, each state perceives 'equity' based on their socio-economic, hydro-meteorological, climatic [98,99], legal and institutional needs [100].

However, from an Islamic water management perspective, if an accord is signed among two communities, e.g., the Helmand River Basin, then the two communities must be fully committed to the implementation of the agreement [101]. Islam puts much emphasis on equity and justice. This equity and justice could also be interpreted in terms of environmental flow and equal utilization of a shared river basin [101]. For instance, the prophet stated, "none of you will have faith till he wishes for his (Muslim) brother what he likes for himself (Sahih Bukhari, vol. 1, book 2, number 12); quoted in [7]. This hadith implies that Islam urges Muslims to consider justice and equity while using freshwater resources [7].

Muslims who prevent others from accessing water are committing a sin. It is narrated that, "the man who has water in excess of his needs, refuses it to a traveler" will be overlooked by Allah on the Day of Judgment (Abu Dawud, 236); quoted in [102]. Islam orders followers to consider fairness and justice in utilizing water resources [56,102-104]. It is argued that lack of enforcement mechanism remains the main challenge to the implementation of Islamic water management principles. The Taliban have expressed commitment to implementing Sharia law in every aspect of life [105].

Although in the modern era western-oriented international water law has served as the main legal framework for the water dispute resolution between Muslim and non-Muslim countries, Naff and Dellapenna assert that due to the lack of an impartial enforcement mechanism, international water law has been unable to solve water disputes between upstream and downstream states of a shared river basin [10,98] (p. 4). Despite Sharia law lacking the proper institutional structures to adjudicate international, political, economic and managerial laws in today's independently secular societies, it does not mean that international law is morally superior to Sharia law because it is institutionally fitted to the modern world. Although all UN member states, especially the Muslim-dominated states, have adhered to western law in the international arena, Sharia law is still applied in many Islamic states [10,51]. Islamic communities are the ones where Islam is the official religion; in countries such as Afghanistan and Iran, Sharia is considered as the source of law [1] (p. 480). In fact, Muslim communities try to adapt all aspects of their lives to the principles of Sharia [5,64]. The use of Islamic water management principles prevails over international water law principles in Islamic dominated states [5], taking equity, responsibility and sustainability criteria into consideration. This is because Sharia law gives equal rights to both upstream users and the downstream users while this principle cannot be observed at the international water law principles. Al-Zuhili believes that "The right to equality in rights and duties and to litigation is natural rights and the latter is complementary to and expressive of the right to justice. Hence no group or person, not even a monarch, should be treated with favoritism or with discrimination over others. The prophet (peace be upon him) says: "People are equal like the teeth of a comb" (narrated by Abu Hatem-ar-Razi); quoted in [50] (p. 276).

However, applying these principles at the inter-basin level, e.g., the Helmand River Basin-for example were the Taliban to allow Iran greater access to water from the Helmand River Basin in return for government recognition and financial support-could significantly harm the flow of the upstream Helmand River Basin in Afghanistan, as well as the Hamoun wetlands within Afghan territory. 


\subsection{Commitment for Cooperation}

In the presence of a poorly developed water treaty, the upstream states occasionally abuse their geographic position [8], whereas the downstream states sometimes take advantage of social unrest in the upstream states [84]. In contrast, Islam considers a community (upstream and downstream communities) as a body of people who cooperate and protect each other and the environment $[16,37,64]$. This principle has been cited in the Quran in various forms, such as forbidding evil, commanding good, institutionalizing equity and justice. The holy Quran, for example, highlights the importance of cooperation at the inter-basin level: "the believers, men and women, are friends and protectors of one another; They all enjoin good and forbid evil, establish prayers, pay zakat (charity), and obey God and His Messenger - these are the ones upon whom God is going to have His mercy. Verily, God is Almighty, Wise!" (Quran, 9:71); quoted in [37]. Moreover, Al-Zuhili argues that cooperation-no matter at the individual or transboundary level-is compulsory for all Muslim nations [50].

Additionally, Islamic water management principles allow each riparian state to enjoy equal distribution of shared water $[5,102,106,107]$. For example, in the traditional way of water allocation in Afghanistan, upstream and downstream users of a shared canal enjoy equal rights to water allocation [106,107]. It is also argued that fitra points to the interaction of people with each other. It vividly highlights how cooperation at all levels of life, e.g., cooperation among co-riparian states of a same river basin $[5,71,108,109]$, is of utmost importance. This cooperation could take place at individual and inter-basin levels [37,110].

\subsection{Posing No Significant Harm}

Despite having an international water treaty on the Helmand River Basin [70], it is believed that Afghanistan maintained control over the use of water in the upstream Helmand River through the construction of dams [69], posing potentially significant harm to downstream Iran and triggering the loss of one million jobs in downstream Iran [2]. As a countermeasure, Iran has equipped the Taliban and other anti-governmental groups to blow up dams in the upstream of the Helmand River Basin $[87,88,90]$. While the upstream co-riparian poses significant harm to the flow of water, some believe that the downstream riparian can also exert significant harm to the "future upstream utilization" [57] (pp. 1-2) of the same watercourse, e.g., the disruption of Kajaki and Kamal Khan Dam construction processes by upstream Iran [111,112]. In fact, such destructive measures either by upstream or downstream users will challenge the responsibility of each co-riparian in addressing the third principle of international water law: posing no significant harm [113,114].

Since international water law principles are very general, the responsibility of each riparian state in posing no significant harm [115] to the environment and the basin remains unclear $[57,99,109]$. This vagueness has forced the co-riparian states to seek alternative legal means for their water sharing dispute, e.g., negotiation of ad hoc interstate dispute settlement arrangements, see also [57,109]. That is why Iran, as the downstream state, has taken different measures to tackle the water crisis in Sistan, Iran $[65,71,88]$ and Afghanistan maintained control over the upstream Helmand River Basin through construction of the Kamal Khan Dam [87,93,111].

On the other hand, Islamic principles of water management command followers to consider justice between each other. That means that if there is any agreement between two communities (e.g., upstream Afghanistan and downstream Iran signed the Helmand River Water Treaty in 1973), both of the communities should remain committed to it [16,37]. The Prophet Mohammad once said; "Muslims must abide by their agreements, unless there is an agreement that makes halal (permitted) what is haram (prohibited) or makes haram what is halal" (reported by Tirmidhi); quoted in [37]. Additionally, it is narrated that the Prophet Mohammad (pbuh) asserts, "don't commit any harm or injury to yourself, and do not cause harm or injury to others" (Al-Baghdadi, 32); quoted in [116]. According to Islamic principles, Muslim nations such as Afghanistan and Iran should address their problems and challenges including water disputes through peace, security, recognition 
of each other's rights and mutual respect [50]. It can be inferred that violating the water rights of either upstream or downstream users is strongly prohibited from an Islamic water management perspective. The Prophet Mohammad also stated, "He who eats to his fill while his neighbor goes without food is not a believer" (Shu'ab Al-Imam-Baihaqui); quoted in [6]. Wickstrom contends that food can be interpreted as irrigation and the neighbor can be interpreted as co-riparian at the inter-basin level [6]. This principle could also be used for maintaining the rights of the ecosystem and the Hamoun wetlands. Muslims are strictly banned from harming the ecosystem $[5,6,15]$. Hence, given drastic climate change alongside the desiccation of the Hamoun wetlands [69], the current water treaty of the Helmand River Basin, which was framed based on international water law principles [69], does not meet environmental sustainability of the basin $[69,95,96,117]$.

\subsection{Maintaining and Preserving the Sustainability of the Ecosystem}

Islam has put much emphasis on the preservation of the environment. The verse, "... . And waste not by excess, for Allah loves not the wasters" (Quran, 7:31); quoted in [118], and the hadith, "A Muslim does not plant a sapling but a man or an animal or a bird eats of it, it is a charity for him till the Day of Resurrection" (Sahih al- Bukhari, 2320); quoted in [119] (p. 15), shed light on the preservation of the environment. As trustees of God, water belongs to God, who entrusted it to mankind to use in a sustainable and equitable manner and to pass it to the next generation without posing significant harm to the ecosystem [21].

Due to the presence of a poorly adapted water treaty between Afghanistan and Iran in the Helmand River Basin, along with the adverse impacts of climate change [65,93], the wetlands have already dried up $[2,3,69]$. The current water treaty of the Helmand River Basin no longer meets the needs of upstream and downstream riparian states [3,69]. We believe that the inclusion of religiously inspired principles into the transboundary water management mechanism of the Helmand River Treaty will help riparian states utilize the flow of the Helmand River Basin in a sustainable and equitable manner.

\subsection{Recognition of Islamic Emirate of Afghanistan at the Expenses of Water Allocation}

In August 2021, the Taliban officially took over Kabul, Afghanistan, putting an end to two decades of the controversial presence of US-led NATO forces in the country [120]. Once established as the government, the Taliban stress that they will rule the country according to Islamic Sharia law [121-123]. Sharia or Islamic law includes all affairs including water governance, especially at the transboundary level, e.g., the transboundary Helmand River Basin. However, the process of implementing Sharia law is gradual as the Taliban are trying to become recognized by UN member countries. Once their regime is recognized by the UN, they will likely expedite the implementation of Islamic law.

Prior to conquering the country, members of the Taliban reportedly travelled to Iran, meeting behind closed doors with Javad Zarif, the Foreign Minister of the Islamic Republic of Iran [124]. Although the Taliban claim that they discussed the peace process with the Iranian counterparts in January 2021, some researchers believe that the Taliban and the Iranian leadership discussed the Helmand River Treaty [125,126]. According to reports, Iran agreed to recognize and support the Islamic Emirate of Afghanistan and the establishment of the Taliban regime in Afghanistan. In return, Iran will be able to freely access water in the transboundary Helmand River Basin.

Due to severe drought and drastic climate change in the region [65], Iranian leadership pressured the elected Afghan president, Ashraf Ghani (during his second term of presidency from 18 February 2020-15 August 2021), to incorporate the wetlands' rights into the agreement by revising the Helmand River Treaty [127]. However, these pressures did not work out. Iran has reportedly accused the former Afghan government "of making the Helmand River into a political tool" [2] (p. 4). On the other side, the Afghan government has repeatedly rejected the claim of not respecting the water rights of Iran. The Atlantic Council, South Asia Center interviewed Najeeb Fahim, the former Director of International Treaties and Conventions at the Afghan Ministry of Foreign Affairs, who said, "in the 
last 40 years Iran has taken several times more water than stipulated by the water treaty between the two countries" [2] (p. 4).

In recent years, both countries have not had good diplomatic relations [125]. Iran has reportedly used the issue of Afghan refugees as a measure to pressure the Afghan government to revisit the Helmand River Treaty. As a countermeasure, the Afghan government has used water as leverage to pressure Iran to respect the rights of Afghan immigrants in Iran $[2,126]$.

The level of tension between the two governments of Iran and Afghanistan has significantly intensified [126], especially when the Independent Election Commission of Afghanistan (IEC) announced the incumbent president, Ashraf Ghani, as the winner of the 2019 presidential election [128]. The Iranian ambassador to Afghanistan, Mr. Bahador Aminian, did not participate in the inaugural ceremony held by Ashraf Ghani [126]. In order to recognize the second presidential term of Ashraf Ghani, Iran has offered the government to revisit the two transboundary river basins, especially the Helmand River Basin, through signing the comprehensive document on Iran-Afghanistan strategic cooperation [129].

The opinion piece of former Minister of Energy and Water of Afghanistan, Ali Ahmad Osmani, has uncovered the adverse consequences of signing the comprehensive document on Iran-Afghanistan strategic cooperation. He argued that signing the comprehensive document on Iran-Afghanistan strategic cooperation will threaten the flow of the Helmand and Harirud River Basins in Afghanistan [129]. Some scholars believe that Iranian counterparts have urged the Afghan government to include the rights of the Hamoun wetlands into the revision of the Helmand River Basin $[129,130]$. While climate change has negatively affected the flow of the wetlands in both Afghanistan and Iran, the Iranian side has been accusing Afghanistan of the Hamoun's desiccation. Hence, Iranian counterparts have been urging the Afghan government (both the government under Ashraf Ghani and the Taliban's administration) to include the wetlands' rights by revising the Helmand River Treaty. In fact, the desiccation of wetlands especially in Iranian territory has pressured Iran to invite the Afghan government to revisit the Helmand River Treaty. It is also contended that senior Afghan officials are in favor of the agreement because of their personal interests. Opponents of the agreement have been fired by the government [129]. However, with the rapid withdrawal of US forces from Afghanistan, this document has not been finalized.

With the establishment of the Islamic Emirate of Afghanistan under the Taliban administration in August 2021, Iran has shown interest in broadening its socio-economic and political relations with the Taliban regime [131,132]. Iran will reportedly back and recognize a Sunni government in the Islamic Emirate of Afghanistan, providing that the Taliban: (a) protect the rights of Shiite minority in Afghanistan; (b) maintain the security of the Afghan-Iranian political border; (c) fight against ISIS and (d) revisit the Helmand River Treaty [131]. According to this agreement, Islamic water management principles-the purist Sharia principles-will be incorporated into the revised Helmand River Treaty.

Given the material, ideational and bargaining power of Iran, the new transboundary water treaty on the Helmand River will possibly allow the Iranian leadership to have greater weight in transboundary water negotiation over the Helmand River Basin than in the past $[129,130]$. On the other hand, the agreement could pressure the Taliban to discontinue the construction of new dams on the upper Helmand River Basin. Therefore, as the Taliban are committed to implementing Sharia law in governing the country [121], the religiously inspired Islamic water management principles may well be incorporated into a new agreement of the transboundary Helmand River.

\section{Conclusions}

Despite the rise of water conflict among Muslim-dominated riparian states, the role of religion, specifically Islam, in the equitable allocation of water resources has been undervalued by scholars. This paper argued why and how Islamic water management and religiously inspired norms will likely be included in the revision of the transboundary Helmand River Treaty under the administration of the Taliban. 
Given the political instability in Afghanistan, along with the rapid withdrawal of US-led NATO forces, the Taliban took over Afghanistan on 15 August 2021. Once their government is established, they have claimed that they will rule Afghanistan based on Islamic principles. These principles can also be applied in water resources management especially at the transboundary water level. However, their government is not recognized by any UN member state. This paper has found that in order to gain recognition by downstream riparian states of the Helmand River Basin (the Islamic Republic of Iran) the Taliban has promised Iran that it will revisit the transboundary Helmand River Treaty based on Islamic principles. According to this agreement, Islamic water management principles may supersede the current principles of the Helmand River Treaty signed in 1973, which could enable the downstream Iran to have more influence in the negotiation and allocation of water resources of the Helmand River Basin. Finally, once the treaty is revised, upstream Afghanistan - under the administration of the Taliban-may have new constraints on the construction of more dams on the tributaries of the upper Helmand River Basin.

Author Contributions: Conceptualization, N.L. and A.T.W.; methodology, N.L.; formal analysis, N.L. and A.T.W.; investigation, N.L. and A.T.W.; resources, N.L.; data curation, N.L.; writing-original draft preparation, N.L. and A.T.W.; writing-review and editing, N.L. and A.T.W.; supervision, A.T.W. All authors have read and agreed to the published version of the manuscript.

Funding: This research received no external funding.

Institutional Review Board Statement: Not applicable.

Informed Consent Statement: Not applicable.

Data Availability Statement: All the data sources have been already cited in the manuscript.

Acknowledgments: The authors acknowledge the financial support from Oregon State University, USA.

Conflicts of Interest: The authors declare no conflict of interest for publishing the paper.

\section{References}

1. Naff, T.; DellaPenna, J. Can there be confluence? A comparative consideration of Western and Islamic fresh water law. Hydrol. Res. 2002, 4, 465-489. [CrossRef]

2. Aman, F. Water Dispute Escalating between Iran and Afghanistan. Available online: www.atlanticcouncil.org/wp-content/ uploads/2016/09/Water_Dispute_Escalating_between_Iran_and_Afghanistan_web_0830.pdf (accessed on 15 August 2020).

3. Thomas, V.; Warner, J. Hydropolitics in the Harirud/Tejen River Basin: Afghanistan as hydro-hegemon? Water Int. 2015, 40, 593-613. [CrossRef]

4. Zeitoun, M.; Warner, J. Hydro-hegemony-A framework for analysis of trans-boundary water conflicts. Hydrol. Res. 2006, 8, 435-460. [CrossRef]

5. Amery, H.A. Islamic Water Management. Water Int. 2001, 26, 481-489. [CrossRef]

6. Brooking, E.T. Before the Taliban Took Afghanistan, It Took the Internet. Available online: www.atlanticcouncil.org/blogs/newatlanticist/before-the-taliban-took-afghanistan-it-took-the-internet/ (accessed on 26 August 2021).

7. Faruqui, N. Islam and Water Management: Overview and Principles. In Water Management in Islam; United Nations University Press: Tokyo, Japan, 2001; pp. 1-32.

8. Wolf, A.T. Indigenous Approaches to Water Conflict Negotiations and Implications for International Waters. Int. Negot. 2000, 5, 357-373. [CrossRef]

9. Lambton, A.K. State and Government in Medieval Islam; Oxford University Press: Oxford, UK, 1981.

10. Naff, T. Islamic Law and the Politics of Water. In The Evolution of the Law and Politics of Water; Springer Science and Business Media LLC: Berlin, Germany, 2009; pp. 37-52.

11. Shroder, J. Water in Islam. In Transboundary Water Resources in Afghanistan; Elsevier: Amsterdam, The Netherlands, 2016; pp. 361-375. [CrossRef]

12. Gaathier, M. Integrated Water Resources Management-An Islamic Perspective. 2017. Available online: https://www.linkedin. $\mathrm{com} /$ pulse/intergrated-water-resources-management-islamic-gaathier-mahed (accessed on 13 February 2021).

13. Gasparatos, A.; El-Haram, M.; Horner, M. A critical review of reductionist approaches for assessing the progress towards sustainability. Environ. Impact Assess. Rev. 2008, 28, 286-311. [CrossRef]

14. Dellapenna, J.; Gupta, J. Toward Global Law on Water. Glob. Gov. A Rev. Multilater. Int. Organ. 2008, 14, 437-453. [CrossRef] 
15. Loodin, N. Aral Sea: An environmental disaster in twentieth century in Central Asia. Model. Earth Syst. Environ. 2020, 6, 2495-2503. [CrossRef]

16. Hussein, I.; Al-Jayyousi, O. Management of shared waters: A comparison of international and Islamic law. In Water Management in Islam; United Nations University Press: Tokyo, Japan, 2001; pp. 128-135.

17. Wilkinson, J.C. Muslim land and water law. J. Islam. Stud. 1990, 1, 54-72. [CrossRef]

18. Varisco, D.M. Sayl and Ghayl: The ecology of water allocation in Yemen. Hum. Ecol. 1983, 11, 365-383. [CrossRef]

19. Norvelle, M.E. Water Use and Ownership According to the Texts of Hanbali Fiqh. Master's Thesis, McGill University, Montreal, Canada, 1974.

20. Mallat, C. The quest for water-use principles: Sharia and custom in the Middle East. In Water in the Middle East. Legal, Political, and Commercial Implications; Allan, J.A., Mallat, C., Eds.; University of London: London, UK, 1995.

21. Ansari, M.I. Islamic Perspectives on Sustainable Development. Am. J. Islam Soc. 1994, 11, 394-402. [CrossRef]

22. Loodin, N.; Keith, T.; Arynova, A.; Rosenblum, Z.; Ruzmatova, Z. A critical analysis of the food-energy-water nexus in the Kootenai River Basin. Sustain. Water Resour. Manag. 2021, 7, 26. [CrossRef]

23. Gada, M. Environmental Ethics in Islam: Principles and Perspectives. 2014. Available online: https://www.researchgate.net/ publication/278727259_Environmental_Ethics_in_Islam_Principles_and_Perspectives (accessed on 27 February 2021).

24. Shomali, M. Aspects of Environmental Ethics: An Islamic Perspective. 2008. Available online: www.thinkingfaith.org (accessed on 10 February 2021).

25. MacAlister, C.; Subramanyam, N. Climate change and adaptive water management: Innovative solutions from the global South. Water Int. 2018, 43, 133-144. [CrossRef]

26. Dien, M.I. Islam and the Environment: Theory and practice. J. Beliefs Values 1997, 18, 47-57. [CrossRef]

27. Abedi-Sarvestani, A.; Shahvali, M. Environmental ETHICS: Toward an Islamic Perspective. 2018. Available online: https://www. researchgate.net/publication/268296827_Environmental_Ethics_Toward_an_Islamic_Perspective (accessed on 26 February 2021).

28. Goralnik, L.; Nelson, M. Anthropocentrism. 2012. Available online: https:/ /www.sciencedirect.com/topics/social-sciences/ anthropocentrism (accessed on 23 February 2021).

29. Wang, E. Animal Liberation Movement and Animal Rights. Available online: https://scholarblogs.emory.edu/millsonph115/201 4/11/17/animal-liberation-movement-and-animal-rights / (accessed on 28 February 2021).

30. Kopnina, H. Ecocentric Education: Student Reflections on Anthropocentrism-Ecocentrism Continuum and Justice. J. Educ. Sustain. Dev. 2019, 13, 5-23. [CrossRef]

31. Mohamed, N. Revitalizing an Eco-Justice Ethic of Islam by Way of Environmental Education: Implications for Islamic Education. Ph.D. Thesis, Stellenbosch University, Stellenbosch, South Africa, 2012. Available online: http:/ /scholar.sun.ac.za (accessed on 8 February 2021).

32. Özdemir, I. Toward an Understanding of Environmental Ethics from a Quranic Perspective. In Islam and Ecology: A Bestowed Trust; Foltz, R.C., Denny, F.M., Baharuddin, A., Eds.; Harvard University Press: Cambridge, UK, 2003; pp. 1-37.

33. Ammar, N. Islam and eco-justice. In The Encyclopedia of Religion and Nature; Bron, R.T., Ed.; Thoemmes Continuum: London, UK, 2005; pp. 862-866.

34. Khalid, F. Islam and the Environment. In Social and Economic Dimensions of Global Environmental Change; Timmerman, P., Ed.; Wiley \& Sons: Hoboken, NJ, USA, 2002; Volume 5, pp. 332-339.

35. Kavezeri-Karuaihe, S.T.; Faruqui, N.I.; Biswa, A.K.; Bino, M.J. Water Management in Islam. J. Range Manag. $2003,56,397$. [CrossRef]

36. Sarkawi, A.A.; Abdullah, A.; Dali, N.M. The Concept of Sustainability from the Islamic Perspectives. Available online: http: / /ijbel.com/wp-content/uploads/2016/06/KLiISC_52.pdf (accessed on 18 December 2020).

37. Al-Jayyousi, O.R. Islam and Sustainable Development: New Worldviews; Gower Pub.: Burlington, VT, USA, 2011.

38. Salman, S.M.A. The Helsinki Rules, the UN Watercourses Convention and the Berlin Rules: Perspectives on International Water Law. Int. J. Water Resour. Dev. 2007, 23, 625-640. [CrossRef]

39. Rahaman, M.M. Principles of international water law: Creating effective transboundary water resources management. Int. J. Sustain. Soc. 2009, 1, 207. [CrossRef]

40. Birnie, P.; Boyle, A. International Law and the Environment; Oxford University Press: New York, NY, USA, 2002.

41. Schroeder-Wildberg, E. The 1997 International Watercourses Convention-Background and Negotiations; Technical University of Berlin: Berlin, Germany, 2002.

42. Abu-Zeid, K. International Water Law from Helsinki Rules to the United Nations Convention on the Law of the Non-Navigational Uses of International Watercourses. Available online: https://www.researchgate.net/publication/282798343_International_ Water_Law_from_Helsinki_Rules_to_the_United_Nations_Convention_on_the_Law_of_the_Non-Navigational_Uses_of_ International_Watercourses (accessed on 18 February 2021).

43. United Nations. Convention on the Law of the Non-Navigational Uses of International Watercourses. 1997. Available online: https://legal.un.org/ilc/texts/instruments/english/conventions/8_3_1997.pdf (accessed on 24 February 2021).

44. Eckstein, G. Development of international water law and the UN watercourse convention. In Hydropolitics in the Developing World: A Southern African Perspective; Turton, A., Henwood, R., Eds.; African Water Issues Research Unit: Pretoria, South Africa, 2002; pp. 81-96. 
45. Khalid, A.R.M. The Interlinking of Rivers Project in India and International Water Law: An Overview. Chin. J. Int. Law 2004, 3 , 553-570. [CrossRef]

46. Milich, L.; Varady, R.G. Openness, sustainability, and public participation: New designs for transboundary river basin in-stitutions. J. Environ. Dev. 1999, 8, 258-306. [CrossRef]

47. Pottinger, L. Can the Nile States dam their way to cooperation? In IRN Backgrounder on the Nile Basin Initiative; International River Network: Berkeley, CA, USA, 2004.

48. Qureshi, A. Water Resources Management in Afghanistan: The Issues and Options. 2002. Available online: https://www researchgate.net/publication/42765588_Water_Resources_Management_in_Afghanistan_The_Issues_and_Options (accessed on 5 September 2020).

49. UN Global Compact. Integrating the SDGs into Corporate Reporting: A Practical Guide. Recuperado de. 2018. Available online: https:/ / www.unglobalcompact.org/docs/publications (accessed on 12 January 2021).

50. Giordano, M.A.; Wolf, A.T. Sharing waters: Post-Rio international trans-boundary water management. Nat. Resour. Forum 2003, 27, 163-171. [CrossRef]

51. Guindi, A. The Islamization of Egypt; Middle East Review of International Affairs; GLORIA Center: Herzliaya, Israel, 2006. Available online: http:/ / meria.idc.ac.il/ (accessed on 16 July 2021).

52. Brownlie, I. Principles of Public International Law, 4th ed.; OUP: Oxford, UK, 1979.

53. Gutoskey, E. What's the Difference between Equity and Equality? Available online: https://www.mentalfloss.com/article/6254 04/equity-vs-equality-what-is-the-difference\#: \{\}:text=Equality $\% 20$ has $\% 20$ to $\% 20$ do $\% 20$ with, the $\% 20$ needs $\% 20$ of $\% 20$ the $\% 20$ recipients (accessed on 25 February 2021).

54. Justice and Equity in Islam. Available online: https://blog.darussalamstore.com/justice-and-equity-in-islam/ (accessed on 26 November 2018).

55. Elias, A. Equality and Equity in Islam. Available online: https://Abuaminaelias.com/ (accessed on 11 December 2020).

56. De Chatel, F. Drops of Faith: Water in Islam. About Islam. Retrieved August 22, 2021. Available online: https://aboutislam.net/ shariah/shariah-and-humanity/shariah-and-life/drops-faith-water-islam/ (accessed on 1 November 2020).

57. McIntyre, O. Responsibility and liability in international law for damage to transboundary fresh water resources. In Research Handbook on Freshwater Law and International Relations; Edward Elgar Publishing: Cheltenham, UK, 2018; pp. 335-365. [CrossRef]

58. Kolstad, C.; Krautkraemer, J. Natural Resource Use and the Environment. In Handbook of Natural Resource and Energy Economics; Kheese, A.K., Sweeney, J.L., Eds.; Elsevier: Amsterdam, The Netherlands, 1991; Volume III.

59. Bassiouni, M. The Social System and Morality of Islam. Available online: https://www.mei.edu/publications/social-systemand-morality-islam (accessed on 24 January 2021).

60. Obaidullah, M. Human Responsibility in Islam. Available online: https://www.daily-sun.com/printversion/details/350513 /Human-responsibility-in-Islam (accessed on 16 October 2021).

61. Kaskas, S.; Hungerford, D. The Qur'an with References to the Bible: A Contemporary Understanding; Bridges of Reconciliation: Fairfax, VA, USA, 2016.

62. Dovers, S.; Handmer, J.W. Uncertainty, sustainability and change. Glob. Environ. Chang. 1992, 2, 262-276. [CrossRef]

63. Hermanowicz, S.W. Sustainability in water resources management: Changes in meaning and perception. Sustain. Sci. 2008, 3, 181-188. [CrossRef]

64. Qadir, J.; Zaman, A. Sustainable Development Viewed from the Lens of Islam. Available online: https://www.researchgate.net/ publication/325946300_Sustainable_Development_Viewed_from_the_Lens_of_Islam (accessed on 5 January 2021).

65. Nagheeby, M.; Piri, M.; Faure, M. The Legitimacy of Dam Development in International Watercourses: A Case Study of the Harirud River Basin. Transnatl. Environ. Law 2019, 8, 247-278. [CrossRef]

66. Nagheeby, M.; Warner, J. The geopolitical overlay of the hydropolitics of the Harirud River Basin. Int. Environ. Agreements Politi-Law Econ. 2018, 18, 839-860. [CrossRef]

67. Hanasz, P. The Politics of Water Security between Afghanistan and Iran; Strategic Analyses Paper; Future Directions International Pty Ltd.: Nedlands, Australia, 2012.

68. Dominguez, F.J.; Lowry, B.L.; Webb, C.E. The Helmand River Basin Dispute. 1951. Available online: https://aquapedia. waterdiplomacy.org/wiki/index.php?title=The_Helmand_River_Basin_Dispute (accessed on 14 December 2020).

69. Thomas, V.; Varzi, M.M. A legal licence for an ecological disaster: The inadequacies of the 1973 Helmand/Hirmand water treaty for sustainable transboundary water resources development. Int. J. Water Resour. Dev. 2015, 31, 499-518. [CrossRef]

70. Goes, B.; Howarth, S.; Wardlaw, R.; Hancock, I.; Parajuli, U. Integrated water resources management in an insecure river basin: A case study of Helmand River Basin, Afghanistan. Int. J. Water Resour. Dev. 2015, 32, 1-23. [CrossRef]

71. Shroder, J.; Ahmadzai, S.J. Transboundary Water Resources in Afghanistan. In Transboundary Water Resources in Afghanistan; Elsevier: Amsterdam, The Netherlands, 2016. [CrossRef]

72. Hensel, P.R.; Mitchell, S.M.; Sowers, T.E. Conflict management of riparian disputes. Politi-Geogr. 2006, 25, 383-411. [CrossRef]

73. Stahl, K. Influence of Hydroclimatology and Socioeconomic Conditions on Water-Related International Relations. Water Int. 2005, 30, 270-282. [CrossRef]

74. Beach, H.L.; Hamner, J.; Hewitt, J.J.; Kaufman, E.; Kurki, A.; Oppenheimer, J.A.; Wolf, A.T. Transboundary Freshwater Dispute Resolution: Theory, Practice, and Annotated References; United Nations University Press: New York, NY, USA, 2000. 
75. Kliot, N. Water Resources and Conflict in the Middle East. 1994. Available online: https://www.routledge.com/Water-Resourcesand-Conflict-in-the-Middle-East/Kliot/p/book/9780415097529 (accessed on 20 February 2021).

76. Petersen-Perlman, J.D.; Veilleux, J.C.; Wolf, A.T. International water conflict and cooperation: Challenges and opportunities. Water Int. 2017, 42, 105-120. [CrossRef]

77. Wolf, A.T.; Natharius, J.A.; Danielson, J.; Ward, B.S.; Pender, J.K. International River Basins of the World. Int. J. Water Resour. Dev. 1999, 15, 387-427. [CrossRef]

78. Wolf, A.; Kramer, A.; Carius, A.; Dabelko, G. Managing Water Conflict and Cooperation. Available online: https://www researchgate.net/publication/230557887_Managing_Water_Conflict_and_Cooperation (accessed on 18 February 2021).

79. Wolf, A.T.; Yoffe, S.B.; Giordano, M. International waters: Identifying basins at risk. Hydrol. Res. 2003, 5, 29-60. [CrossRef]

80. Eliasson, J. The rising pressure of global water shortages. Nat. Cell Biol. 2014, 517, 6-7. [CrossRef]

81. Al-Zuhili, S.W. Islam and International Law; International Review of the Red Cross; Cambridge University Press: Cambridge, UK, 2005; Volume 87, Number 858.

82. Wickström, L. Islamic Guiding Principles on Water Management. 2010. Available online: www.scribd.com/document/24529885 2/Islamic-guiding-principles-on-water-management (accessed on 10 March 2021).

83. Asia Water. Transboundary Water Disputes between Afghanistan and Iran. Climate. In Water and Post-Conflict Peacebuilding Nakayama, M., Earls, L., Weinthal, E., Troell, J.J., Eds.; Routledge: London, UK, 2014. Available online: https:/ / climate-diplomacy. org/case-studies/transboundary-water-disputes-between-afghanistan-and-iran (accessed on 21 March 2021).

84. Shroder, J. Hydro-Hegemony in Afghanistan and Surrounding Countries. In Transboundary Water Resources in Afghanistan; Elsevier: Amsterdam, The Netherlands, 2016; pp. 339-359.

85. Ahmadi, N. Water Reservoir Springs New Life into Community in Northern Afghanistan. $2016 . \quad$ Available online: https://www.unicef.org/afghanistan/stories/water-reservoir-springs-new-life-community-northern-afghanistan (accessed on 28 August 2016).

86. Sonn, T. Tawhid. In Oxford Encyclopedia of the Modern Islamic World; Oxford University Press: Oxford, UK, 1995.

87. Ali. Nimroz Residents Vow to Safeguard Kamal Khan Dam from Iranian Plots. Available online: https://afghanistan.asia-news. com/en_GB/articles/cnmi_st/features/2020/10/29/feature-01 (accessed on 29 October 2020).

88. Omar. Pashdan Dam Construction Moves Ahead Despite Iranian Sabotage Efforts. Available online: https://afghanistan.asianews.com/en_GB/articles/cnmi_st/features/2020/04/08/feature-02 (accessed on 12 May 2020).

89. Ramachandran, S. India's Controversial Afghanistan Dams, The Diplomat. Available online: https://thediplomat.com/2018/08/ indias-controversial-afghanistan-dams/ (accessed on 12 August 2020).

90. Rasmussen, S. On the Edge of Afghanistan. Available online: https://foreignpolicy.com/2017/09/12/on-the-edge-ofafghanistan-taliban-iran-war-united-states / (accessed on 13 January 2021).

91. Goulet, D. Development experts: The one-eyed giants. World Dev. 1980, 8, 481-489. [CrossRef]

92. Khoshnood, A.; Khoshnood, A. The death of an emperor-Mohammad Reza Shah Pahlavi and his political cancer. Alex. J. Med. 2016, 52, 201-208. [CrossRef]

93. Sadat, S.; Sayed, N. Afghanistan and Iran: From Water Treaty to Water Dispute. Available online: https://www.lowyinstitute. org/the-interpreter/afghanistan-and-iran-water-treaty-water-dispute (accessed on 13 January 2021).

94. Al-Zuhili, S.W. Islam and International Law; Routledge: London, UK, 2017; pp. 79-93.

95. Amini, A. Understanding 1973 the Helmand Treaty by Invoking Rules of Interpretation According to Vienna Convention. 1969. Department of Water and Irrigation. Available online: https://jwim.ut.ac.ir/article_82737.html (accessed on 23 August 2021).

96. Wilkinson, J. Islamic water law with special reference to oasis settlement. J. Arid. Environ. 1978, 1, 87-96. [CrossRef]

97. McIntyre, O. Water, Law and Equity. In The Human Face of Water Security; Springer: Singapore, 2017; Volume 25, pp. 45-70.

98. Moore, I. Water Sharing Regimes in Israel and the Occupied Territories a Technical Analysis; Project Report 609; Operational Research and Analysis Establishment, Department of National Defense: Ottawa, Canada, 1992.

99. McIntyre, O. Environmental Protection of International Watercourses under International Law; Routledge: London, UK, 2016.

100. Zwarteveen, M.; Kemerink-Seyoum, J.S.; Kooy, M.; Evers, J.; Guerrero, T.A.; Batubara, B.; Biza, A.; Boakye-Ansah, A.; Faber, S.; Flamini, A.C.; et al. Engaging with the politics of water governance. Wiley Interdiscip. Rev. Water 2017, 4. [CrossRef]

101. Al-Jayyousi, O. Islam and Water Management and the Dublin Statement. In Water Management in Islam; United Nations University Press: Tokyo, Japan, 2001; pp. 33-38.

102. Ali, A. The Taliban Have Reportedly Promised to Supply Water to Iran in Return for Support (رايورونو له يخي طالبانو د ملاتي زه (كي انران ته د اوبو وركولو زمنه كري ده . Afghanistan Asia News, Salaam Times. Available online: https://Afghani-stan.asia-news. com/ps/articles/cnmi_st/features/2021/02/25/feature-01 (accessed on 25 February 2021).

103. De Chatel, F. Drops of Faith: Water in Islam. Available online: https://aboutislam.net/shariah/shariah-and-humanity/shariahand-life/drops-faith-water-islam/ (accessed on 21 April 2016).

104. De Châtel, F. Perceptions of Water in the Middle East: The Role of Religion, Politics and Technology in Concealing the Growing Water Scarcity. In Water Resources in the Middle East; Springer: Berlin/Heidelberg, Germany, 2007; pp. 53-60. [CrossRef]

105. Karimi, N.; Rahim, F. Iran Hosts High-Level Afghan Peace Talks as Fighting SURGES. Available online: www.military.com/dailynews/2021/07/08/iran-hosts-high-level-afghan-peace-talks-fighting-surges.html (accessed on 8 July 2021).

106. Abdullaev, I.; Shah, U. Community water management in northern Afghanistan: Social fabric and management performance. Int. J. Environ. Stud. 2011, 68, 333-341. [CrossRef] 
107. Lee, J.L. Water Management, Livestock and the Opium Economy: The Performance of Community Water Management Systems; Afghanistan Research and Evaluation Unit: Kabul, Afghanistan, 2007.

108. Asyraf, H.; Syahrin, S.; Hailan, S.; Hamdan, A. Sustainable Development from Islamic Perspective. 2018. Available online: https:/ / www.researchgate.net/publication/325100693_Sustainable_development_from_islamic_perspective (accessed on 18 December 2020).

109. McIntyre, O. The current state of development of the no significant harm principle: How far have we come? Int. Environ. Agreem. Politi-Law Econ. 2020, 20, 601-618. [CrossRef]

110. Johnson, T.; Sergie, M. Islam: Governing under Sharia. Council on Foreign Relations. Available online: https://www.cfr.org/ backgrounder/islam-governing-under-sharia (accessed on 1 November 2021).

111. BBC Pashto. كمال خان بند بشير:بدو سره د اران يارلمان كي يري غونهه وشوه Bbc.Com/Pashto. Available online: https://www.bbc. com/pashto/afghanistan-55628673 (accessed on 12 August 2021).

112. Glinski, S. God, Gas and Heroin. Now, the Fight's over Water. 2020. Available online: https://www.latimes.com/world-nation/ story/2020-02-06/afghanistan-and-iran-battle-over-water-with-spies-bribes-and-threats (accessed on 8 June 2020).

113. Schmeier, S. Prior notification of planned measures: A response to the no-harm dilemma? Int. Environ. Agreem. Politi-Law Econ. 2020, 20, 683-698. [CrossRef]

114. Ziganshina, D.; Janusz-Pawletta, B. The principle of no significant harm in the Central Asian context. Int. Environ. Agreem. Politi-Law Econ. 2020, 20, 713-730. [CrossRef]

115. Gunasekara, N.K.; Kazama, S.; Yamazaki, D.; Oki, T. Water Conflict Risk due to Water Resource Availability and Unequal Distribution. Water Resour. Manag. 2014, 28, 169-184. [CrossRef]

116. Al Baghdadi. Collection of the Sciences and Wisdom, 5th ed.; Dar Al Manhal: Cairo, IL, USA, 1982.

117. Bidabadi, F.S.; Afshari, L. Human Right to Water in the Helmand Basin: Setting a Path for the Conflict Settlement between Afghanistan and Iran. Utrecht Law Rev. 2020, 16, 300-312. [CrossRef]

118. Abderrahman, W.A. Water Demand Management and Islamic Water Management Principles: A Case Study. Int. J. Water Resour. Dev. 2000, 16, 465-473. [CrossRef]

119. Osmani, A.A. منابع آب افغانستان در گرودار برجام معكوس انران(Afghanistan's Water Resources Are in the Grip of Iran's Reverse Cycle). روزنامه رصبح. Available online: https://8am.af/afghanistans-water-resources-are-in-the-grip-of-irans-reverse-cycle/ (accessed on 31 October 2021).

120. Seir, A.; Faiez, R.; Akhgar, T.; Gambrell, J. Taliban Sweep into Afghan Capital after Government Collapses. 2021. Available online: Apnews.com/article/afghanistan-taliban-kabul-bagram-e1ed33fe0c665ee67ba132c51b8e32a5 (accessed on 16 August 2021).

121. British Broadcast Corporation, BBC. What Is Sharia Law? What Does It Mean for Women in Afghanistan? Available online: www.bbc.com/news/world-27307249 (accessed on 19 August 2021).

122. Lister, T. Barbers Banned from Shaving Beards and Playing Music in Afghanistan's Helmand Province. CNN, Cable News Network. Available online: www.cnn.com/2021/09/26/world/taliban-afghanistan-beards-music-intl/index.html (accessed on 26 September 2021).

123. The Associated Press. Taliban Official Says Strict Punishment and Executions Will Return. NPR, NPR. Available online: www.npr. org/2021/09/24/1040339286/taliban-official-says-strict-punishment-and-executions-will-return (accessed on 24 September 2021).

124. Shahriar, Z. Doesn't Iran Recognize Ashraf Ghani's Government? (آنا ابران دولت اشرف غنى را به رسمست نمششناسد). BBC News فارسى, BBC. Available online: www.bbc.com/persian/afghanistan-51955799 (accessed on 19 March 2020).

125. Abdul Basir, A. Water Should Be Removed from the Comprehensive Strategic Partnership Document between Afghanistan and Iran (حذف شود 》سند جامع راهبردى همكارى مان افغنستان و انران«آب باد از) 8AM Newspaper. Available online: https:// 8am.af/water-should-be-removed-from-the-comprehensive-strategic-partnership-document-between-afghanistan-and-iran (accessed on 20 July 2020).

126. Zarei, S. US Black Box in Afghanistan [نادداشت روز)جعبه ساه آمرس در افغانستان)]. Available online: https://www.mashreghnews. ir/news /1273263/\%D8\%AC\%D8\%B9\%D8\%A8\%D9\%87-\%D8\%B3\%DB\%8C\%D8\%A7\%D9\%87-\%D8\%A2\%D9\%85\%D8\%B1

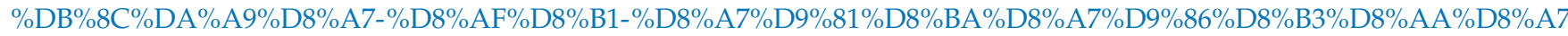
$\%$ D9\%86. (accessed on 19 September 2021).

127. Mayar, A. Water in the Afghanistan-Iran Strategic Agreement (دافغانستاناران يه ستراتثك ترون كي د اوبو برخه). Tolonews, 25 July 2020. Available online: https://tolonews.com/pa/opinion/\%D8\%AF-\%D8\%A7\%D9\%81\%D8\%BA\%D8\%A7\%D9\%86\% D8\%B3\%D8\%AA\%D8\%A7\%D9\%86-\%D8\%A7\%DB\%8C\%D8\%B1\%D8\%A7\%D9\%86-\%D9\%BE\%D9\%87-\%D8\%B3\%D8\%AA\% D8\%B1\%D8\%A7\%D8\%AA\%DB\%8C\%DA\%98\%DB\%8C\%DA\%A9-\%D8\%AA\%DA\%93\%D9\%88\%D9\%86-\%DA\%A9\%DB\%90 -\%D8\%AF- \%D8\%A7\%D9\%88\%D8\%A8\%D9\%88-\%D8\%A8\%D8\%B1\%D8\%AE\%D9\%87. (accessed on 1 October 2021).

128. Sleet, P. Water Sharing Tensions between Iran and Afghanistan Still High as Droughts Ease. Future Directions International. Available online: https:/ / www.futuredirections.org.au/publication/water-sharing-tensions-between-iran-and-afghanistanstill-high-as-droughts-ease/ (accessed on 1 November 2021).

129. Cookman, C. Another Afghan ELECTION Crisis and the Challenge of Power-Sharing. Available online: www.usip.org/ publications / 2020/03/another-afghan-election-crisis-and-challenge-power-sharing (accessed on 10 March 2020). 
130. Farshad, A.; Zinck, J.A. Traditional Irrigation Water Harvesting and Management in Semiarid Western Iran: A Case Study of the Hamadan Region. Water Int. 1998, 23, 146-154. [CrossRef]

131. Kumar, R.; Hikmat, N. Why Iran Is Deporting Scores of Afghan Refugees. Foreign Policy. Available online: https:/ / foreignpolicy. com/2020/01/13/why-iran-is-deporting-scores-of-afghan-refugees / (accessed on 13 January 2021).

132. Kittleson, S. Why Iran Will Welcome the Taliban Takeover in Afghanistan. Foreign Policy. Available online: https:/ / foreignpolicy. com/2021/08/18/why-iran-will-welcome-the-taliban-takeover-in-afghanistan/ (accessed on 18 August 2021). 